\title{
An Exploratory Study on the Experience Requirements of Key HRM jobs in Sri Lanka
}

\author{
A.Anton Arulrajah \\ Senior Lecturer \\ Department of Management \\ Faculty of Commerce and Management \\ Eastern University \\ E-mail: antonarulrajah@yahoo.com \\ And \\ H.H.D.N.P. Opatha \\ Professor of HRM (on Merit) \\ Department of HRM \\ Faculty of Management Studies and Commerce \\ University of Sri Jayewardenepura \\ E-mail: hopatha@yahoo.com
}

\begin{abstract}
It has been generally observed that there is a gap in the empirical knowledge with regard to the experience requirements of key HRM jobs in terms of number of years and contents of experiences in the field of HRM in Sri Lanka. The research questions of this exploratory study are: What are the experiences needed or expected by the organizations which are operating in Sri Lanka for key HRM jobs in terms of number of years and contents? and Is it possible to develop a sort of illustration to understand experience requirements of key HRM jobs in Sri Lanka? Objectives of this study are to explore the experience requirements of key HRM jobs in terms of number of years and contents; and to develop an illustration of experience requirements of key HRM jobs in Sri Lanka. In order to achieve the objectives of this research, an exploratory study was conducted by using eight key HRM job related employment advertisements appeared in the Sunday Observer newspaper for the period of 5 years (2006, 2007, 2008, 2009 and 2010). This study was longitudinal in time horizon. The unit of analysis of this study was HRM related job advertisement. The extent of the researchers' interference in this study was minimal as there had not been any manipulation and control of variables. This study was carried out in a natural (non-contrived) environment where events occurred normally.
\end{abstract}

Mainly by using comprehensive and systematic content analysis along with descriptive statistics, results and findings were generated. The results of the study revealed that the experience requirement is one of the very important requirements in selecting people for key HRM jobs. At the same time it varies from job to job. When considering the experience requirements for the selected key HRM jobs, the findings revealed that mostly a minimum of 
5-10 years experience at senior level (as a HR Manager/Head of HR Department) is needed experience for the post of HR Director. A minimum of 5 years experience is needed for the post of Head of HRM, Group HR Manager, HR Manager and Training Manager mostly. For $H R$ Executive, HR Officer and Recruitment Manager a minimum of 2-3 years experience is expected by the organizations which are operating in Sri Lanka.

With regard to the contents (quality) of experiences, eight (08) key dimensions of experience were identified in addition to the number of years (quantity) such as general experience in HRM field, special experience in specific HRM area/function, scope of experience in HRM field (local or international), sector related experience, management level/position related experience, industry related experience, workforcelorganisation size based experience and time preference based experience. Based on identified key dimensions of experiences, a model was developed from this exploratory study in order to provide an understanding about the experience requirements of selected key HRM jobs in Sri Lanka. The implications of these findings are useful to all stakeholders of HRM especially current and potential job seekers, organizations and HRM workforce developers in Sri Lanka.

Key Words: Key HRM Jobs, Experience Requirements, Exploratory Study

\section{Introduction}

The job experience is one of the very important requirements in selecting a candidate for a job in an organisation. Experience is one of the key human qualifications needed to perform a job efficiently and effectively. At the same time, job experience is a specific requirement to each field in order to perform specific jobs in the respective field such as marketing, accounting, finance, and human resource management etc.

\section{The Research Problem}

Organisations which are operating in Sri Lanka expect experienced people in order to manage their HRM activities and functions efficiently and effectively. But there is a gap in the empirical knowledge with regard to requirements of HRM job experience in Sri Lanka. There is no or little research based evidence in Sri Lanka regarding this phenomenon. No clear cut specifications (number of year [quantity], density and timing [quality] for HRM jobs in Sri Lanka seem to be in existence because various organisations state different levels (in years) and contents of experience in their HRM job advertisements. By studying their experience requirements carefully only it is possible to develop a sort of good framework to specify the Sri Lankan organizations' HRM jobs experience patterns and contents.

Therefore to explore the experience requirements of the HRM jobs which are expected by the organizations in Sri Lanka is an important research task in the field of HRM in Sri Lanka. With a view of filling this empirical knowledge gap to a certain significant extent, this research was carried out. 


\section{The Research Questions}

The research questions of this exploratory study are:

1. What are the experiences needed or expected by the organizations which are operating in Sri Lanka for key HRM jobs in terms of number of years and contents? and

2. Is it possible to develop a sort of illustration to understand experience requirements of key HRM jobs in Sri Lanka?

\section{Objectives of the Study}

Objectives of this study are:

1. To explore the experience requirements of key HRM jobs in terms of number of years and contents; and

2. To develop an illustration of experience requirements of key HRM jobs in Sri Lanka.

\section{Literature Review}

According to Opatha (2007, p.75), experience in the field of HRM is very important for HR managers. It was defined as number of years of working in HRM related job/s. Regarding experience requirements for HRM jobs in Sri Lanka, Opatha (2009) has expressed his views in the following way:

"HRM is an academic discipline as well as a practice, and therefore experience becomes indispensable. Experience refers to knowledge and skills in HRM one has gained owing to his/her working in HRM for a considerable period of time. Experience of a job is what a person gains by doing that job. Observations reveal that a minimum of 10 years experience in a recognised establishment at Senior Executive Level (as a HR Manager/Head of HR Department) is needed as the right experience for the post of HR Director/Assistant GMHR/Deputy GM-HR/Group HR Manager/Group Director-HR (job is in the top management of the organisation). A minimum of 5 years experience is needed for the post of HR manager (job is in middle management of the organization). A large organization usually requires hands-on experience in HRM of not less than 10 years in a leading company".

Research on the impact of job experience on job performance should be viewed cautiously, however, because most studies have measured job experience as the number of years in an organisation or job. Quinones, Ford, and Techout (1995) pointed out that job experience can be viewed not only in terms of quantity but also in terms of quality. Year of working is a quantitative measure of experience. If job experience is viewed qualitatively, this has to be with the job tasks performed and the relevance to situations one has been exposed to on the job. For instance, if an individual has several years of experience as an accountant, but has conducted few field audits, that person will not necessarily perform better in an auditing position than an individual who has less general accounting experience.

Building on the work of Quinones et al. (1995), Tesluk and Jacobs (1998) proposed that job experience can also be viewed in terms of both the density and timing of job-related experiences. When experience has high density, the employee is exposed to many "developmental experiences" in a relative short period of time. These may include increased 
responsibilities, and perhaps even being required to perform under very difficult conditions. The timing dimension has to be with the fact that certain experiences might have more or less, developmental value, depending on whether they occur at the beginning, middle, or latter stage of one's career. For most employees, mistakes have a greater developmental impact when they occur at the early (as opposed to latter) stages of one's career. The more important point from the work of Quinones et al. (1995) and Tesluk and Jacobs (1998) is that job experience is a complex variable, and much theoretical and empirical work needs to be done before fully understanding and appreciating it.

Job Experience is a variable that is used so frequently in organisational psychology that it is easy to forget about it. Typically, most researchers do not pay too much attention to it because they measure it either for descriptive purposes or to use as a control variable in statistical analyses. In the vast majority of studies, experience is measured simply as the number of months or years that a person has been employed on a particular job or in a particular organization.

In a review, Tesluk and Jacobs (1998) pointed out that organisational or job tenure is not likely to capture the complexity of job experience. They pointed out, for example, that the same length of tenure may be very different in terms of both the density and time of jobrelated experiences. A good example of the density dimension is a surgeon who performs in a war zone. This individual would typically do surgeries for many hours per day, and would thus acquire more surgical experience in three months than a surgeon at a regular civilian hospital would acquire in three months or even in six months. A good example of timing is a manager who has to take over a poorly performing department immediately after completing his or her training. Such an experience would undoubtedly have a greater impact on this individual now than it would later in his or her career.

Many organisations recognize complexity of experience and attempt to structure the assignment of high-potential managers in a way that maximizes their developmental value. For the most part, however, researchers have treated experience in a very simplistic fashion. In the future, this is likely to be a very fruitful area of research in organizational psychology (Tesluk and Jacobs, 1998).

Regarding job experience also, there is no or little research based evidence in Sri Lanka. No clear cut ranges or specifications (number of year [quantity], density and timing [quality] for HRM jobs are in existence in Sri Lanka. Different levels (in years) and contents of experience in HRM job advertisements are stated by various organisations. There is a need of exploring these differences and reaching towards a framework that specifies general features of the experience requirements.

\section{Methodology}

An exploratory study was conducted by using eight key HRM job related employment advertisements appeared in the Sunday Observer newspaper for the period of 5 years (2006, 
2007, 2008, 2009 and 2010) in order to achieve the objectives of the research. Time horizon of the study was longitudinal and the unit of analysis of the study was HRM related job advertisement. Because of the reason that any manipulation and control of variables had not been done, the extent of the researchers' interference in this study was minimal. In a natural environment where events occurred normally this study was carried out.

\section{Findings and Discussion}

During the study period, a total of 3374 HRM job advertisements were collected from the organizations which are operating in Sri Lanka in all the sectors and out of which 1429 were related to the selected key HRM jobs which included Director-HR, Group Human Resource Manager, Head-HRM, Manager-HRM, HR Executive, HR Officer, Training Manager and Recruitment Manager. Results and findings were generated by exploring all the data in the light of research objectives.

Table 1 gives number of job advertisements and number of job vacancies relating to the advertisements for the selected 08 key jobs under study. According to the Table 1, the key job that had the highest number of job advertisements and vacancies is HR Manager. HR Executive is the key job that had the next highest number of advertisements and vacancies. These two jobs are critical for a person who wants to excel in the HRM profession. Generally the job of HR Manager becomes a long term career goal and the job of HR Executive becomes a short term career goal for a person who wishes to have an excellent career in the field of HRM. Tables from 2 to 17 provide experience requirements for the eight key HRM jobs in terms of years and contents.

Table: 1 Key HRM Jobs: Number of Job Advertisements/Vacancies

\begin{tabular}{|l|c|c|c|c|c|c|}
\hline \multirow{2}{*}{ Selected Key HRM Jobs } & \multicolumn{5}{|c|}{ Year } & \multirow{2}{*}{ Total } \\
\cline { 2 - 6 } & $\mathbf{2 0 0 6}$ & $\mathbf{2 0 0 7}$ & $\mathbf{2 0 0 8}$ & $\mathbf{2 0 0 9}$ & $\mathbf{2 0 1 0}$ & \\
\hline HR Director & & & & & & \\
\hline No. of Job Advertisements & 07 & 20 & 11 & 05 & 13 & $\mathbf{5 6}$ \\
\hline Number of Job Vacancies & 07 & 20 & 11 & 05 & 14 & $\mathbf{5 7}$ \\
\hline Group HR Manager & & & & & & \\
\hline No. of Job Advertisements & 07 & 06 & 05 & 02 & 05 & $\mathbf{2 5}$ \\
\hline Number of Job Vacancies & 07 & 06 & 05 & 02 & 05 & $\mathbf{2 5}$ \\
\hline Head-HRM & & & & & & \\
\hline No. of Job Advertisements & 08 & 08 & 07 & 06 & 05 & $\mathbf{3 4}$ \\
\hline Number of Job Vacancies & 08 & 08 & 07 & 06 & 06 & $\mathbf{3 5}$ \\
\hline HR Manager & & & & & & \\
\hline No. of Job Advertisements & 116 & 139 & 130 & 63 & 114 & $\mathbf{5 6 2}$ \\
\hline Number of Job Vacancies & 122 & 147 & 160 & 68 & 121 & $\mathbf{6 1 8}$ \\
\hline HR Executive & & & & & & \\
\hline No. of Job Advertisements & 101 & 120 & 102 & 40 & 91 & $\mathbf{4 5 4}$ \\
\hline Number of Job Vacancies & 117 & 159 & 132 & 46 & 102 & $\mathbf{5 5 6}$ \\
\hline HR Officer & & & & & & \\
\hline
\end{tabular}




\begin{tabular}{|l|c|c|c|c|c|c|}
\hline No. of Job Advertisements & 27 & 35 & 28 & 27 & 41 & $\mathbf{1 5 8}$ \\
\hline Number of Job Vacancies & 35 & 36 & 30 & 53 & 44 & $\mathbf{1 9 8}$ \\
\hline Training Manager & & & & & & \\
\hline No. of Job Advertisements & 12 & 14 & 27 & 04 & 23 & $\mathbf{8 0}$ \\
\hline Number of Job Vacancies & 14 & 14 & 27 & 04 & 27 & $\mathbf{8 6}$ \\
\hline Recruitment Manager & & & & & & \\
\hline No. of Job Advertisements & 08 & 10 & 15 & 08 & 19 & $\mathbf{6 0}$ \\
\hline Number of Job Vacancies & 08 & 11 & 17 & 08 & 20 & $\mathbf{6 4}$ \\
\hline Note: Excluding Repetition & & & & \\
\hline
\end{tabular}

\section{Director Human Resources and Related Jobs}

Table: 2 Experience and Director-HR and Related Jobs in Terms of Years

\begin{tabular}{|l|c|c|}
\hline Experience in Years & Frequency & $(\mathbf{\%})$ \\
\hline Minimum 05 Years & 20 & 36 \\
\hline Minimum 06 Years & 01 & 02 \\
\hline Minimum 07 Years & 01 & 02 \\
\hline Minimum 08 Years & 05 & 08 \\
\hline Minimum 10 Years & 11 & 20 \\
\hline Minimum 15 Years & 11 & 20 \\
\hline Minimum 18 Years & 01 & 02 \\
\hline Minimum 20 Years & 01 & 02 \\
\hline Years Not specified & 05 & 08 \\
\hline Total & $\mathbf{5 6}$ & $\mathbf{1 0 0}$ \\
\hline
\end{tabular}

Table: 3 Experience and Director-HR and Related Jobs in Terms of Contents

\begin{tabular}{|c|l|c|}
\hline$\#$ & Contents & Count \\
\hline 01 & Experience in HRM/HR Field/Function & 52 \\
\hline 02 & Experience in Senior Management Level/Position & 29 \\
\hline 03 & Experience in Administrative/ Administrative Function & 16 \\
\hline 04 & Experience in Leadership position/Strategic Leadership position & 08 \\
\hline 05 & Experience in Management/Managerial Capacity/Position & 07 \\
\hline 06 & Experience in Executive Capacity/Level & 07 \\
\hline 07 & Experience in Public/Government Sector Organisation & 06 \\
\hline 08 & Experience in Recognized Public/State/Gov. Corporation & 05 \\
\hline 09 & Experience in Private Sector Organisation & 05 \\
\hline 10 & Professional Experience & 05 \\
\hline 11 & Experience in INGOs/NGOs/ Service Oriented Organisation & 04 \\
\hline 12 & Experience in Manufacturing Organisation/Firms & 03 \\
\hline 13 & Experience in Multi-Cultural and Multinational organisations (MNCs) & 02 \\
\hline 14 & Expatriates in donor funded product implementation-Experience & 01 \\
\hline 15 & Experience in Banking Industry & 01 \\
\hline
\end{tabular}




\section{Group Human Resource Manager (GHRM)}

Table: 4 Experience and GHRM in Terms of Years

\begin{tabular}{|l|c|c|}
\hline Experience in Years & Frequency & $\mathbf{( \% )}$ \\
\hline Minimum 03 Years & 04 & 16 \\
\hline Minimum 04 Years & 01 & 04 \\
\hline Minimum 05 Years & 10 & 40 \\
\hline Minimum 06 Years & 01 & 04 \\
\hline Minimum 10 Years & 04 & 16 \\
\hline Minimum 15 Years & 02 & 08 \\
\hline Years Not specified & 03 & 12 \\
\hline Total & $\mathbf{2 5}$ & $\mathbf{1 0 0}$ \\
\hline
\end{tabular}

Table: 5 Experience and GHRM in Terms of Contents

\begin{tabular}{|l|l|c|}
\hline$\#$ & Contents & Count \\
\hline 01 & HRM/HR Field/Function & 22 \\
\hline 02 & Experience in Similar Capacity & 09 \\
\hline 03 & Senior Management Level/Position & 07 \\
\hline 04 & Garment Industry/Manufacturing & 06 \\
\hline 05 & Experience in a reputed/recognised organisation/company & 05 \\
\hline 06 & Experience in Management/Managerial Capacity/Position & 03 \\
\hline 07 & Experience in Service Oriented Organisation & 02 \\
\hline 08 & Experience based on workforce size (e.g. 4000) & 02 \\
\hline 09 & Expatriates in a Blue Chip Company & 01 \\
\hline 10 & Experience in Banking Industry & 01 \\
\hline 11 & $\begin{array}{l}\text { Experience in liaising with the EFC, BOI and handling } \\
\text { negotiation with TU }\end{array}$ & 01 \\
\hline
\end{tabular}

\section{Head of Human Resource (Head-HRM)}

Table: 6 Experience and Head-HRM in Terms of Years

\begin{tabular}{|l|c|c|}
\hline Experience in Years & Frequency & $\mathbf{( \% )}$ \\
\hline Minimum 04 Years & 01 & 03 \\
\hline Minimum 05 Years & 22 & 65 \\
\hline Minimum 10 Years & 04 & 12 \\
\hline Minimum 15 Years & 01 & 03 \\
\hline Years Not specified & 06 & 17 \\
\hline & $\mathbf{3 4}$ & $\mathbf{1 0 0}$ \\
\hline
\end{tabular}

Table: 7 Experience and Head-HRM in Terms of Contents

\begin{tabular}{|l|l|c|}
\hline$\#$ & Contents & Count \\
\hline 01 & Relevant work experience/similar capacity (as Head of the HR function) & 23 \\
\hline
\end{tabular}




\begin{tabular}{|l|l|c|}
\hline 02 & Experience in a managerial capacity/position/level & 12 \\
\hline 03 & Experience in handling and managing the HR functions of an organization & 09 \\
\hline 04 & Senior management level experience & 09 \\
\hline 05 & $\begin{array}{l}\text { Industry/sector experience (finance/banking/manufacturing/service oriented } \\
\text { organisation/related field/ others) }\end{array}$ & 08 \\
\hline 06 & Experience in developing and implementing modern HR practices & 05 \\
\hline 07 & Experience at a lager/Medium sized or reputed organization & 04 \\
\hline
\end{tabular}

\section{Human Resource Manager (Manager-HRM)}

Table: 8 Experience and HR Manager in Terms of Years

\begin{tabular}{|l|c|c|}
\hline Experience in Years & Total & $\mathbf{( \% )}$ \\
\hline Minimum 01 Year & 07 & 01 \\
\hline Minimum 02 Years & 24 & 04 \\
\hline Minimum 03 Years & 104 & 19 \\
\hline Minimum 04 Years & 18 & 03 \\
\hline Minimum 05 Years & 193 & 35 \\
\hline Minimum 06 Years & 07 & 01 \\
\hline Minimum 07 Years & 10 & 02 \\
\hline Minimum 08 Years & 13 & 02 \\
\hline Minimum 10 Years & 39 & 07 \\
\hline Minimum 12 Years & 04 & 01 \\
\hline Minimum 15 Years & 02 & 00 \\
\hline Minimum 18 Years & 02 & 00 \\
\hline Years Not specified & 139 & 25 \\
\hline Total & $\mathbf{5 6 2}$ & $\mathbf{1 0 0}$ \\
\hline
\end{tabular}

Table: 9 Experience and HR Manager in Terms of Contents

\begin{tabular}{|c|l|c|}
\hline \multicolumn{1}{|l|}{ त } & Contents & Count \\
\hline 01 & Experience in HRM/HR Field/Function & 299 \\
\hline 02 & Similar Capacity/Position (As HR Manager) & 165 \\
\hline 03 & Experience in Specific HR Functions/Areas & 127 \\
\hline 04 & Experience in Manufacturing Organisation/Firms & 53 \\
\hline 05 & Experience in Senior Management Level/Position & 49 \\
\hline 06 & Experience in Garment/Apparel Industry & 47 \\
\hline 07 & Experience in Management/Managerial Capacity/Position & 43 \\
\hline 08 & Experience in MNCs/Large MNCs Work Experience & 34 \\
\hline 09 & Hands on Experience in ...(Last ..2 Years) & 34 \\
\hline 10 & Experience in Well Reputed Establishment/Firm/Organisation/Company & 31 \\
\hline 11 & Experience in Factory/Plant Work Environment & 26 \\
\hline 12 & Experience based on Size of the Workforce (E.g. Over 1000/1500, etc.,) & 23 \\
\hline
\end{tabular}




\begin{tabular}{|c|c|c|}
\hline 13 & Experience in Administrative Function & 23 \\
\hline 14 & Experience in Hotel/ Tourism/ Hospitality Trade & 16 \\
\hline 15 & Experience in Private Sector Organisation & 13 \\
\hline 16 & Experience in Executive Capacity/Level & 12 \\
\hline 17 & Leadership Experience & 12 \\
\hline 18 & Experience in Recognised Public Enterprise/Organisation & 11 \\
\hline 19 & Experience in BOI Approved Factory/Company & 09 \\
\hline 20 & Experience in Large Size/Scale Organisation/Corporation & 09 \\
\hline 21 & Experience in Reputed Service Sector Organisation & 09 \\
\hline 22 & Experience in HR Generalist Role & 08 \\
\hline 23 & Experience in HRD & 08 \\
\hline 24 & Experience in INGOs/NGOs & 08 \\
\hline 25 & Experience in ICT/Software Industry & 07 \\
\hline 26 & Experience in Banking/Insurance Industry & 06 \\
\hline 27 & Experience in Group HR Operations & 06 \\
\hline 28 & Experience in Construction Industry & 04 \\
\hline 29 & Experience in Export/Import Related Industry & 04 \\
\hline 30 & Experience in Middle Level Management & 04 \\
\hline 31 & Experience in Multi-cultural team & 04 \\
\hline 32 & Armed Service Experience & 03 \\
\hline 33 & Experience as a Manager & 03 \\
\hline 34 & Experience in a Senior Executive Level & 03 \\
\hline 35 & Experience in Hospital/Health Care Sector & 03 \\
\hline 36 & Experience in Similar Sized Organisation & 03 \\
\hline 37 & Experience in Telecommunication Sector & 03 \\
\hline 38 & Experience in Handling Projects & 02 \\
\hline 39 & Experience in Retail Sector & 02 \\
\hline 40 & Experience in Blue Chip Company/Organisation & 01 \\
\hline 41 & Experience in Comparable Organization & 01 \\
\hline 42 & Experience in Marine Company & 01 \\
\hline
\end{tabular}

\section{Human Resource Executive (HR Executive)}

Table: 10 Experience and HR Executive in Terms of Years

\begin{tabular}{|l|c|c|}
\hline Experience in Years & Total & $\mathbf{( \% )}$ \\
\hline Minimum 06 Months & 01 & 00 \\
\hline Minimum 01 Year & 33 & 07 \\
\hline Minimum 02 Years & 130 & 29 \\
\hline Minimum 03 Years & 122 & 27 \\
\hline Minimum 04 Years & 12 & 03 \\
\hline Minimum 05 Years & 44 & 10 \\
\hline Year(s) Not specified & 112 & 24 \\
\hline
\end{tabular}




\section{Total}

Table: 11 Experience and HR Executive in Terms of Contents

\begin{tabular}{|c|c|c|}
\hline \# & Contents & Count \\
\hline 01 & Experience in HRM Function/Field & 343 \\
\hline 02 & Similar Capacity/Position (As HR Executive) & 135 \\
\hline 03 & Experience in Manufacturing Organisation/Firms & 64 \\
\hline 04 & Experience in Specific HR Functions/Areas & 57 \\
\hline 05 & Experience in Garment/Apparel Industry & 49 \\
\hline 06 & Experience in Administrative Function & 28 \\
\hline 07 & Hands on Experience in ...(Last ..2 Years) & 25 \\
\hline 08 & Experience in Handling HRIS/MIS/IT/Computerized Environment & 21 \\
\hline 09 & Experience in Well Reputed Establishment/Firm/Organisation & 21 \\
\hline 10 & Experience in Factory/Plan Work Environment & 18 \\
\hline 11 & Experience in Hotel/Tourism/Hospitality Trade & 18 \\
\hline 12 & Experience in MNCs/MNCs Work Experience & 12 \\
\hline 13 & Experience in Executive Capacity & 09 \\
\hline 14 & Experience in Reputed Service Sector Oriented Organisation & 09 \\
\hline 15 & Experience in Current HR Practices & 08 \\
\hline 16 & Experience in an Industrial Setting and Mercantile & 07 \\
\hline 17 & Experience in HRD & 07 \\
\hline 18 & Experience in Large Size/Scale Organisation & 07 \\
\hline 19 & Experience based on Size of the Workforce (E.g. Over 6000) & 06 \\
\hline 20 & Experience in ISO Certified Company and Quality Management System & 06 \\
\hline 21 & Experience in a Well Organised Effective HR Dept./Division & 05 \\
\hline 22 & Experience in Recognised Public Enterprise & 05 \\
\hline 23 & Experience in 5S/Productivity Related Work & 04 \\
\hline 24 & Experience in BOI Approved Companies & 04 \\
\hline 25 & Experience in Private Sector & 04 \\
\hline 26 & Experience in Recognize Commercial Enterprise & 04 \\
\hline 27 & Experience in Construction Industry & 03 \\
\hline 28 & Experience in a Blue-Chip & 02 \\
\hline 29 & Experience in Exporting Organisation & 02 \\
\hline 30 & Experience in Hospital/Health Care Sector & 02 \\
\hline 31 & Experience in Retail Trade & 02 \\
\hline 32 & Experience in Similar Organisation & 02 \\
\hline 33 & Experience in Structuring/Restructuring the HR \& Admin & 02 \\
\hline 34 & Experience as HR Assistant & 01 \\
\hline 35 & Experience in a Junior Executive Capacity & 01 \\
\hline 36 & Experience in Accounting & 01 \\
\hline
\end{tabular}




\begin{tabular}{|r|l|c|}
37 & Experience in Attached to a Dynamic Organization/Company & 01 \\
\hline 38 & Experience in Banking Industry & 01 \\
\hline 39 & Experience in Comparable Organization & 01 \\
\hline 40 & Experience in Food Industry & 01 \\
\hline 41 & Experience in HR Generalist Functions & 01 \\
\hline 42 & Experience in ICT Industry & 01 \\
\hline 43 & Experience in Managerial Level & 01 \\
\hline 43 & Experience in Middle Level Management & 01 \\
\hline 45 & Experience in Organising Events & 01 \\
\hline 46 & Experience in Recognised Organisation & 01 \\
\hline 47 & Experience in Marketing & 01 \\
\hline
\end{tabular}

\section{Human Resource Officer (HR Officer)}

Table: 12 Experience and HR Officer in Terms of Years

\begin{tabular}{|l|c|c|}
\hline Experience in Years & Total & $(\boldsymbol{\%})$ \\
\hline Minimum 01 Year & 12 & 08 \\
\hline Minimum 02 Years & 35 & 22 \\
\hline Minimum 03 Years & 33 & 21 \\
\hline Minimum 04 Years & 01 & 01 \\
\hline Minimum 05 Years & 31 & 19 \\
\hline Year(s) Not specified & 46 & 29 \\
\hline Total & $\mathbf{1 5 8}$ & $\mathbf{1 0 0}$ \\
\hline
\end{tabular}

Table: 13 Experience and HR Officer in Terms of Contents

\begin{tabular}{|c|l|c|}
\hline$\#$ & Contents & Count \\
\hline 01 & Experience in HRM Function/Field & 68 \\
\hline 02 & Experience as a Junior Executive or Supervisory Level/Capacity & 29 \\
\hline 03 & Experience in a mercantile organization & 27 \\
\hline 04 & Experience in a Reputed Organisation & 20 \\
\hline 05 & Experience in a Well Organized Effective HR Dept./Division & 08 \\
\hline 06 & Experience in Administrative Function/Administration & 07 \\
\hline 07 & Experience in Executive Level & 05 \\
\hline 08 & Experience in Garment Manufacturing Industry & 04 \\
\hline 09 & Experience in Government Organisation & 04 \\
\hline 10 & Experience in Hotel Industry & 04 \\
\hline 11 & Experience in International Organisation & 02 \\
\hline 12 & Experience in Large Size/Scale Organisation & 02 \\
\hline 13 & Experience in Manufacturing Organisation/Firms & 02 \\
\hline 14 & Experience in Multi-Cultural Teams & 02 \\
\hline 15 & Experience in non-governmental organisation & 02 \\
\hline
\end{tabular}




\begin{tabular}{|l|l|c|}
16 & Experience in Office Management & 02 \\
\hline 17 & Experience in Policy/Procedure development and implementation & 02 \\
\hline 18 & Experience in Professional Organisations & 02 \\
\hline 19 & Experience in Project Management works & 02 \\
\hline 20 & Experience in Public/Private Sector organisation & 01 \\
\hline 21 & Experience in Similar company/organisation & 01 \\
\hline 22 & Experience in Specific HR Functions/Areas & 01 \\
\hline 23 & Hands on Experience in ...(Last ..2 Years) & 01 \\
\hline 24 & Management Experience & 01 \\
\hline 25 & Related Work Experience & 01 \\
\hline 26 & Similar Capacity/Position (As HR Officer) & 01 \\
\hline
\end{tabular}

\section{Training Manager}

Table: 14 Experience and Training Manager in Terms of Years

\begin{tabular}{|l|c|c|}
\hline Experience in Years & Total & $\mathbf{( \% )}$ \\
\hline Minimum 02 Years & 12 & 15 \\
\hline Minimum 03 Years & 06 & 08 \\
\hline Minimum 04 Years & 06 & 08 \\
\hline Minimum 05 Years & 18 & 22 \\
\hline Minimum 06 Years & 02 & 02 \\
\hline Minimum 10 Years & 03 & 04 \\
\hline Year(s) Not specified & 33 & 41 \\
\hline Total & $\mathbf{8 0}$ & $\mathbf{1 0 0}$ \\
\hline
\end{tabular}

Table: 15 Experience and Training Manager in Terms of Contents

\begin{tabular}{|c|l|c|}
\hline$\#$ & Contents & Count \\
\hline 01 & Similar Capacity/Position (As Training Manager) & 28 \\
\hline 02 & Experience in Specific Industry (Hotel, Manufacturing, Service, banking etc) & 22 \\
\hline 03 & Experience in Training and Development & 19 \\
\hline 04 & Experience in HRM Function/Field & 13 \\
\hline 05 & Experience in Training Role & 11 \\
\hline 06 & Hands on Experience in ...(Last ..x Years in Training ) & 03 \\
\hline 07 & Experience in Senior Manager & 02 \\
\hline 08 & Experience in Reputed Institute & 02 \\
\hline 09 & Experience in non-governmental organisation & 02 \\
\hline 10 & Managerial Experience & 02 \\
\hline 11 & Managerial Experience in Training & 01 \\
\hline 12 & Experience in TTT ( Train the Trainer) & 01 \\
\hline 13 & Experience in Blue Chip Companies & 01 \\
\hline 14 & Experience in Government Organizational Training & 01 \\
\hline
\end{tabular}




\begin{tabular}{|l|l|l|}
\hline 15 & Experience in Managerial Capacity & 01 \\
\hline 16 & Experience in Administrative Function & 01 \\
\hline 17 & Experience in Manufacturing Organisation & 01 \\
\hline
\end{tabular}

\section{Recruitment Manager}

Table: 16 Experience and Recruitment Manager in Terms of Years

\begin{tabular}{|l|c|c|}
\hline Number of Years & Frequency & $(\mathbf{\% )}$ \\
\hline Minimum 2-3 years & 03 & 05 \\
\hline Minimum 3 years & 04 & 07 \\
\hline Minimum 3-4 years & 02 & 03 \\
\hline Minimum 5 years & 02 & 03 \\
\hline Specified but number of years not mentioned & 30 & 50 \\
\hline Not specified & 19 & 32 \\
\hline Total & $\mathbf{6 0}$ & $\mathbf{1 0 0}$ \\
\hline
\end{tabular}

Table: 17 Experience and Recruitment Manager in Terms of Contents

\begin{tabular}{|l|l|c|}
\hline$\#$ & Contents & Count \\
\hline 01 & Exp. in foreign employment/overseas recruiting agency & 25 \\
\hline 02 & Experience in recruitment function of HR & 16 \\
\hline 03 & Hands on experience in recruitment functions & 05 \\
\hline 04 & Recruitment experience in reputed organisation & 03 \\
\hline 05 & Recruitment experience in a labour intensive industry & 02 \\
\hline
\end{tabular}

\section{Discussion}

Regarding the concept of HRM job experience there are two main ideas emerged from this study such as years of experience and contents of experience. In this discussion, first researchers discuss about years of experience expected by the organizations and then focus on contents of experience.

The following Table shows the summary of high frequencies of years of experience for each job from the earlier presentation.

Table: 18 Key HRM Jobs and Most Frequently Required Years of Experience

\begin{tabular}{|c|l|c|c|c|}
\hline$\#$ & \multicolumn{1}{|c|}{ HRM Jobs } & Frequency (Overall) & $\mathbf{( \% )}$ & $\begin{array}{c}\text { Minimum } \\
\text { number of years }\end{array}$ \\
\hline 01 & Director-HR/HRM & 20 out of 56 & $36 \%$ & 05 years \\
\hline 02 & Group HR Manager & 10 out of 25 & $40 \%$ & 05 years \\
\hline 03 & Head of HR & 22 out of 34 & $65 \%$ & 05 years \\
\hline 04 & HR Manager & 193 out of 562 & $35 \%$ & 05 years \\
\hline 05 & HR Executive & 130 out of 454 & $29 \%$ & 02 years \\
\hline & HR Executive & 122 out of 454 & $27 \%$ & 03 years \\
\hline
\end{tabular}




\begin{tabular}{|c|l|c|c|c|}
\hline 06 & HR Officer & 35 out of 158 & $22 \%$ & 02 years \\
\hline & HR Officer & 33 out of 158 & $21 \%$ & 03 years \\
\hline 07 & Training Manager & 18 out of 80 & $22 \%$ & 05 years \\
\hline 08 & Recruitment Manager & 04 out of 60 & $07 \%$ & 03 years \\
\hline & Recruitment Manager & 03 out of 60 & $05 \%$ & $02-03$ years \\
\hline
\end{tabular}

With regard to experience requirements for HRM jobs in Sri Lanka, what Opatha (2009, p.51) has expressed based on his observations is confirmed by the findings of this study. He stated that a minimum of 10 years experience in a recognised establishment at Senior Executive Level (as a HR Manager/Head of HR Department) is needed as the right experience for the post of HR Director/Assistant GM-HR/Deputy GM-HR/Group HR Manager/Group Director-HR (job is in the top management of the organisation). According to this study, as the accumulated experience to become a Director-HR/HRM or similar senior position, a minimum of 10 years experience in a well reputed or recognized organisation (private/public) is needed in Sri Lanka. In addition, he pointed out that a minimum of 5 years experience is needed for the post of HR Manager (job is in middle management of the organization). That is also true, because evidence from this research confirmed that as well.

Other important aspect in experience is contents of experience in addition to the years of experience (number of years of experience). According to this study, under the data analysis of each selected job, the expected contents of experience were presented. After careful investigation of those contents, certain key factors/elements have been identified regarding generalized HRM jobs. In connection with selected HRM jobs, organizations have expressed in their job advertisements in respect of contents of job experience in the following ways (see Exhibit 1).

Exhibit 1 Contents and Emerging Dimensions of HRM Job Experience

\begin{tabular}{|c|c|c|}
\hline \# & $\begin{array}{l}\text { Real world requirements of HRM job } \\
\text { experience }\end{array}$ & Emerging Perspectives/Dimensions \\
\hline 01 & $\begin{array}{l}3 \text { years working experience in a similar } \\
\text { capacity/minimum of } 3 \text { years experience } \\
\text { in the HRM field. }\end{array}$ & \multirow{2}{*}{$\begin{array}{l}\text { 1.HRM Field related experience in } \\
\text { General(Generalization) }\end{array}$} \\
\hline 02 & $\begin{array}{l}\text { The ideal candidate must possess a } \\
\text { minimum of } 8 \text { years experience in a } \\
\text { generalist HR role within the garment } \\
\text { industry. }\end{array}$ & \\
\hline 03 & $\begin{array}{l}\text { Candidates must have } 5 \text { years experience } \\
\text { in HRM especially in Industrial } \\
\text { Relations. }\end{array}$ & $\begin{array}{l}\text { 2. Function within the field or } \\
\text { specialized experience within field. } \\
\text { (Specialization related experience) }\end{array}$ \\
\hline 04 & $\begin{array}{l}\text { Candidates should have at least } 5 \text { years } \\
\text { of relevant experience at the national or } \\
\text { international level in HRM. }\end{array}$ & $\begin{array}{l}\text { 3. Scope related experience } \\
\text { (Local/National HRM or International } \\
\text { HRM) }\end{array}$ \\
\hline 05 & Candidates must have 10 years & 4. Sector related experience \\
\hline
\end{tabular}




\begin{tabular}{|c|c|c|}
\hline & $\begin{array}{l}\text { experience in Private sector/Private } \\
\text { sector organisations. }\end{array}$ & (Private/public/NGO/INGO) \\
\hline 06 & $\begin{array}{l}\text { Minimum of } 10 \text { years post qualifying } \\
\text { experience, of which at least } 5 \text { year } \\
\text { should be in a senior management } \\
\text { position. }\end{array}$ & $\begin{array}{l}\text { 5. Level/position related } \\
\text { experience(Senior/Middle/Operational } \\
\text { level) }\end{array}$ \\
\hline 07 & $\begin{array}{l}\text { Previous experience in a similar position } \\
\text { is preferred and experience in the hotel } \\
\text { trade is an added advantage. }\end{array}$ & \multirow{2}{*}{$\begin{array}{l}\text { 6. Industry related experience } \\
\text { (Hotel/Banking/Garment/ } \\
\text { Manufacturing etc.) }\end{array}$} \\
\hline 08 & $\begin{array}{l}\text { Minimum of } 3 \text { years experience in a } \\
\text { similar capacity, preferably in a } \\
\text { manufacturing plant is also required. }\end{array}$ & \\
\hline 09 & $\begin{array}{l}\text { The position called for an individual with } \\
\text { experience in handling a workforce of } \\
\text { over } 500 \text { employees. }\end{array}$ & 7. Workforce size based experience \\
\hline 10 & Recent/Current hands on experience & 8. Time preference related experience \\
\hline
\end{tabular}

From the above real requirements of the organizations, after conducting content analysis it was possible for researchers to formulate a model of HRM job experience contents in the Sri Lankan context. The Figure 1 shows the emerging model of HRM job experience contents developed from this exploratory study. Even though organizations use number of years in a particular job or organization as a common measurement, really the HRM job experiences contain multiple dimensions and perspectives. Experience contents for specialized HRM jobs such as Training Manager or Recruitment Manager etc include experience in respective area as very important in terms of scope as well as depth.

Findings of this study lead to accept view points of Quinones et al (1995) relating to quantity and quality of job experience. As far as quality or content of experience in HRM jobs is concerned, this study has gone beyond one step further from their views and confirmed that HRM job experience is not only a complex variable but also a multidimensional and broader concept framing eight (08) dimensions which were emphasized by the organizations in assessing quality of HRM job experience in Sri Lanka (see Figure 1). 
Figure 1 Dimensions of HRM Job Experience

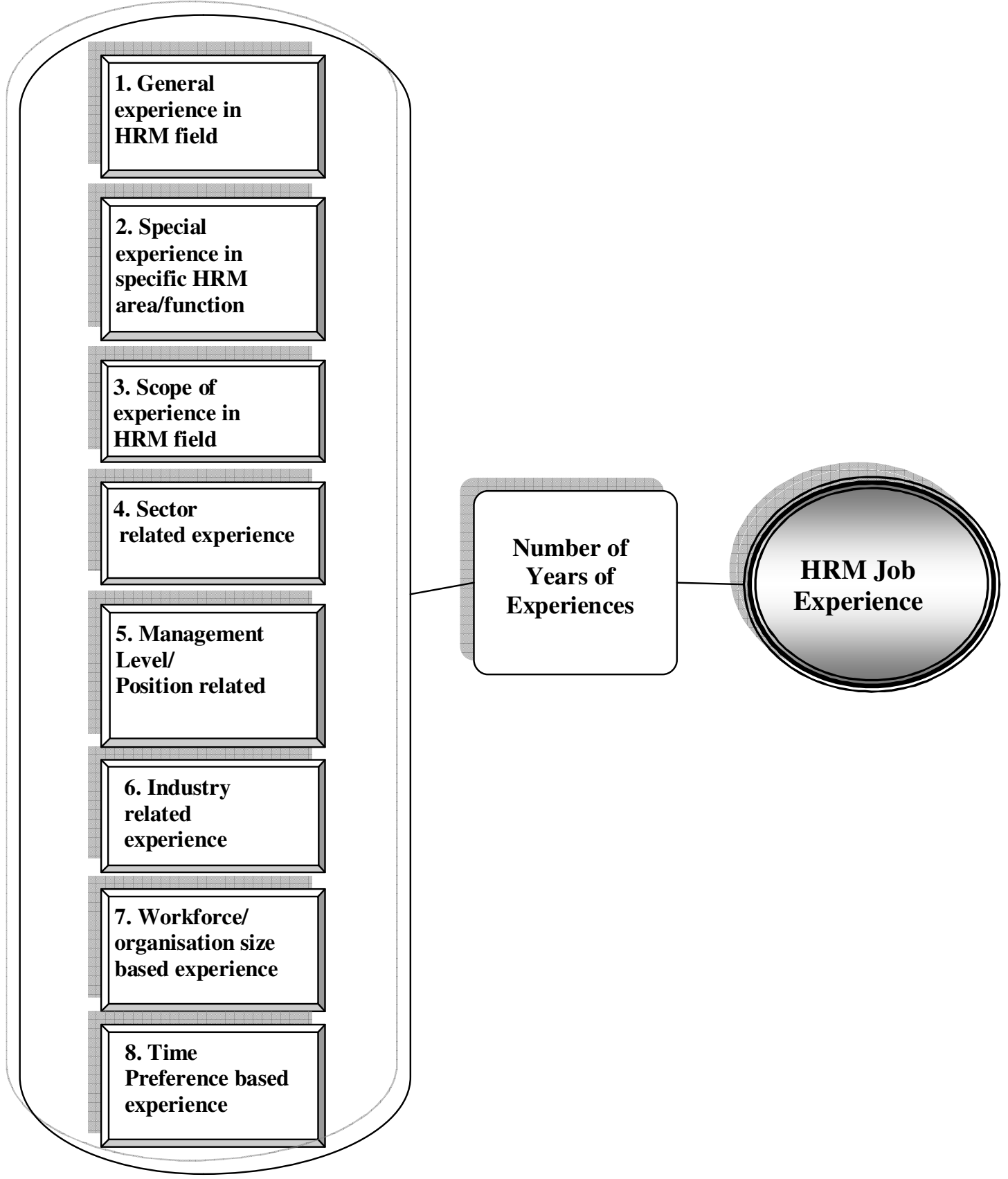

\section{Conclusions}

With regard to experience for top level HRM jobs (Director-HR/HRM, Group HR Manager, Head of HR,) a minimum of five years of experience in senior positions is the most frequently (commonly) expected/needed level of experience by the organizations in Sri Lanka. However, in the perspective of accumulated experience to the top/senior HRM positions, a minimum of 10 years is required. Regarding HR Manager and Training Manager, a minimum of five years of experience in similar positions is the most frequently (commonly) expected/needed level of experience by the organizations in Sri Lanka. Here 
also in the view of accumulated experience, it is a minimum of 05-07 years in Sri Lanka. For HR Executive, HR Officer and Recruitment Manager an experience of 02-03 years is the most frequently (commonly) expected/needed level of experience by the organizations in Sri Lanka.

Career progress/advancement in the HRM field can be earned by gaining experience in different levels. The content of HRM job experience is a multidimensional and broader concept for HRM jobs. In connection with contents of HRM job experience, eight dimensions have been identified from this study including general experience in HRM field, specialized experience in specific HRM area/function, scope of experience in HRM field, sector related experience, management level/position related experience, industry related experience, workforce/organisation size based experience and time preference based experience. In respect of experience contents for specialized HRM jobs such as Training Manager or Recruitment Manager etc, experience in his/her respective area is very important in terms of scope as well as depth.

HRM job experience is one of the essential human qualifications for HRM jobs, and therefore current HRM job holders and potential HRM job seekers should know about these requirements to progress in their HRM career in a successful manner. At the same time, regarding experience contents of generalized HRM jobs, to understand the dimensions required by the organizations in Sri Lanka, and to plan based on that understanding in order to acquire or gain expected experience contents are of very importance to the current HRM job holders and potential HRM job seekers in Sri Lanka. Findings of the study will be useful for career planning and development of persons who choose HRM field as their career field.

\section{References}

Anderson, V. (2005), Research Methods in Human Resource Management, London: Chartered Institute of Personnel and Development.

Creswell, J. (2003), Research Design: Qualitative, Quantitative, and Mix Methods Approaches. Thousand Oaks, California: Sage Publications.

Ghosh, P.L., and Ghorpade, M.B. (2005), Industrial Psychology, $4^{\text {th }}$ ed, Mumbai: Himalaya Publishing House.

Morkes, A. (2004), International Encyclopedia of Careers and Vocational Guidance, $12^{\text {th }}$ Indian Edition, Vol.1: Career Guidance and Career Field Profiles, New Delhi: Viva Books Private Limited.

Opatha, H.H.D.N.P. (2003), Research Methods for Human Resource Management: Questions and Answers. Part 1, Colombo: Author Publication.

Opatha, H.H.D.N.P. (2009), Human Resource Management: Personnel, Colombo: Department of HRM, University of Jayewardenepura.

Quinones, M.A., Ford, J.K., and Techout, M.S. (1995), The relationship between work experience and job performance: A conceptual and meta-analytic review. Personal Psychology Vol.48, No.4, pp.887-894. 
Sajeewanie, T.L and Opatha, H.H.D.N.P. (2007), Relationships between HR Manager- related Factors and Practice of SHRM in Sri Lankan Listed Firms, Sri Lankan Journal of Human Resource Management, Vol.1, No.1, pp.71-87.

Serasinghe, D.K.S and Opatha, H.H.D.N.P. (2007), Human Resource Management Practices in Listed Firms in Sri Lanka, Sri Lankan Journal of Human Resource Management, Vol. 1, No.1, pp.71-83.

Tesluk, P.E., and Jacobs, R.R.(1998), Toward an integrated model of work experience. Personnel Psychology, Vol.51, No.2, pp.321-355. 